\title{
Manufacturing Algebra Keni Pipe to Construct an Understanding of Mathematics Concepts Students
}

\author{
Slamet Soro ${ }^{1}$, Yunda Kurniawan ${ }^{2}$, Hulwa Kurnia ${ }^{3}$ \\ \{slamet.soro@yahoo.co.id ${ }^{1}$ \} \\ Universitas Muhammadiyah Prof Dr Hamka, Indonesia ${ }^{123}$
}

\begin{abstract}
This research is a quantitative study and uses the experimental research method of the Quasi-Experimental type with the type of Nonequivalent Posttest-Only Control Group Design. The population of this study was 274 students consisting of 7 th grade of Junior High School State 13 Jakarta in the even semester of the 2018/2019 academic year. The sample studied was 67 students in the VII-2 class and VII-3 class. In this study, data collection techniques used the instrument of mathematical concept understanding ability that has been validated and has a high level of reliability. The prerequisite tests were normality test and homogeneity test. Normality test results obtained experimental class L_hit $=0,1466<0,1477=$ L_tab and control class L_hit $=0,1466<0,1477=$ L_tab, therefore both classes are from normally distributed populations. Homogeneity test results obtained by the experimental class and control class are not homogeneous. Hypothesis test for inhomogeneous data is using the MannWhitney test. Mann-Whitney test results obtained by Z_hit of -2.60 which resulted in rejecting H_0 at a significance level of 0,05 with an Effect Size of 0,6227 which is classified as moderate. Therefore, it is concluded that there is an effect of algebra Keni pipe teaching aid to construct students' understanding of mathematical concepts.
\end{abstract}

Keywords: mathematical concept; understanding ability; algebra Keni pipe; teaching aids

\section{Introduction}

Mathematics is a subject that is widely applied in daily life such as buying and selling, calculating income, calculating the area of a house, selection of recruitment, and so on. Agustina (2016: 1) said that Mathematics as one of the basic sciences, both its applied aspects and its reasoning aspects, has an important role in the mastery of science and technology. Therefore, a person must master mathematics correctly to increase innovation in the fields of science and technology.

The purpose of learning mathematics is intended to develop reasoning which is an important skill that must be possessed by students (Nahdi 2015: 14). Reasoning power needs to be possessed by all human beings to be able to distinguish between what is right and what is wrong, also encourage humans to keep growing to adapt in an environment that is always changing continuously. In learning activities at school, mathematical activities can foster students' reasoning and creativity in solving a problem. Mathematical activities are carried out by students such as logical and scientific questions and answers, problem solving, causal relations, etc. but the fact is that mathematics is generally feared and considered difficult by some students. 
One factor is because some teachers still use conventional methods when learning in the classroom so learning seems boring and makes students feel bored. It can affect learning outcomes that are less than optimal. To find out the level of success in the teaching and learning process, it can be seen from the learning outcomes achieved by students.

The importance of understanding mathematical concepts is seen in the first aim of learning mathematics according to the Ministry of National Education (Permendiknas no 22 of 2006), namely understanding mathematical concepts, explaining the interrelationships between concepts and applying concepts or algorithms flexibly, accurately, efficiently and precisely in problem solving. Following the objectives of learning mathematics above, after the learning process students are expected to understand a mathematical concept so that they can use these abilities in dealing with mathematical problems.

The ability to understand concepts is part of student mathematics learning outcomes. The ability to understand concepts is a core ability for students to have. According to Eggen and Kauchak (2012), students' knowledge and understanding of a concept can be measured in four ways, namely, we can ask them to: (1) define the concept; (2) identify the concept characters; (3) link concepts with other concepts; (4) identify or give examples of concepts that have not been encountered before. Hence students having the ability to conceptual means that students understand correctly about a design or abstract idea/concept that is being studied.

Teaching aids are necessary as learning media for achieving educational goals. Teaching aids in mathematics can increase effectiveness and efficiency in the learning process. Poerwadarminta in Hermana (1984: 47) said that a tool is an item about something that can be used to achieve an intention. While the visual aid is a tool to show the lesson. Teaching aids are not to replace the position of educators but have a role as a tool to help students learn mathematical concepts from concrete objects to understand abstract mathematical concepts. Abstract learning makes students' thinking and perceptions different. The purpose of using teaching aids in learning is to establish the equal perceptions and understandings of students for students are easier to develop abstract material. Students' memory will improve because students gain new experiences from learning.

According to Asra in Rahma (2018: 37) stated that teaching aids having utilities as follows: (1) clarifying the message to not make it too verbalize, (2) overcoming the limitations of space, time, energy and sense power, (3) generating enthusiasm for learning, more direct interaction between students and learning resources, (4) enabling children to learn independently according to their talents and their visual, auditory and kinesthetic abilities, (5) providing the same stimuli, equalizing experiences and giving rise to the same perceptions. The use of teaching aids is valuable in the learning process. Hermana (1984: 46) said that it will be able to increase the effectiveness, efficiency, and equitable achievement of educational or teaching goals for students. If the knowledge that is supposed to be given to students is not conveyed properly then to overcome the problem, the teacher can use the media in the form of teaching aids in helping to convey mathematical material that requires visualization.

The algebraic Keni pipe is suitable for material systems of linear equations in one variable. It uses sticks/pencils stating the magnitude of the variables and constants. Common mistakes that occur when teachers teach systems of linear equation in one variable to students by moving segments or changing marks. It supposes to subtract, add up, multiply each segment with the same number. Therefore, this teaching aid is suitable for learning mathematics and justifying the true concept of systems of linear equation in one variable. Based on some of the above description, the writer wants to research on manufacturing algebraic Keni pipe to construct the ability to understand students' mathematical concepts. 


\section{Method}

The method in this study uses a quasi-experimental method. The research design used is The Nonequivalent Posttest-Only Control Group. According to Lestari (2017: 136-137), the research design can be described as follows:

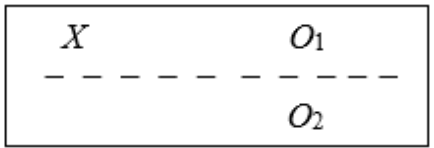

Fig 1. Research Design

Note:

$\mathrm{X} \quad:$ The treatment in the experimental class used algebraic teaching aids

$O_{1} \quad$ : Giving posttest to the experimental class

$\mathrm{O}_{2} \quad$ : Giving posttest to the control class

$R \quad:$ The two classes are randomly selected

$\quad$ - $-\quad$ : Cluster Random Sampling

The population of this study was students of State Junior High School 13 Jakarta, with the sample was students of grades VII-2 and VII-3 in the 2018/2019 academic year. The sampling technique used was cluster random sampling, the selected class was VII-3 as the experimental class and class VII-2 as the control class. The instrument used was the posttest and the instrument in this study used a mathematics learning achievement test. The number of questions used to measure students' mathematical concept comprehension skills is 8 posttest questions in the form of a description of the material in system linear equations in one variable.

\section{Result and Discussion}

Based on the results of data analysis, the following is a summary of the results of normality with the Lilliefors test presented in Table 1 below.

Table 1. Normality Test Results After Treatment

\begin{tabular}{|c|c|c|c|c|c|}
\hline Class & $\begin{array}{c}\text { The number } \\
\text { of sample }\end{array}$ & $\begin{array}{c}\text { Significance } \\
\text { Level }\end{array}$ & $\boldsymbol{L}_{\text {count }}$ & $\boldsymbol{L}_{\text {table }}$ & Note \\
\hline Experiment & 36 & 0,05 & 0,1466 & 0,1477 & Normal \\
\hline Control & 31 & 0,05 & 0,1240 & 0,1591 & Normal \\
\hline
\end{tabular}

Based on the normality test results of the two classes presented in Table 1 shows the experimental class and the control class is normally distributed. Next, the homogeneity test is performed with the test results presented in Table 2 below.

Table 2. Homogeneity Test Results After Treatment

\begin{tabular}{|c|c|c|c|c|}
\hline Class & $\begin{array}{c}\text { The number of } \\
\text { student }\end{array}$ & $\begin{array}{c}\text { Significance } \\
\text { Level }\end{array}$ & $\boldsymbol{F}_{\text {count }}$ & \multirow{2}{*}{$\boldsymbol{F}_{\text {table }}$} \\
\hline VII-2 & 31 & 0,05 & 1,8836 & 1,7856 \\
\hline VII-3 & 36 & 0,05 & \multicolumn{2}{|c|}{ Data Not Homogeneous } \\
\hline \multicolumn{4}{|c|}{ conclusion } & \multicolumn{4}{c}{}
\end{tabular}


Based on the results of the homogeneity test in Table 2, it can be concluded that the two classes are in a non-homogeneous condition. Furthermore, the Mann-Whitney test was carried out with the following test results. The two variances non-parametric test between the experimental class and the control class was performed using the Mann-Whitney test. If seen from the value of $p=0,0047<0,05=\alpha$, it can be said that $\mathrm{H}_{-} 0$ rejects. This means that the two classes have an effect on the discovery learning model assisted by algebraic learning aids on student mathematics learning outcomes.

Based on the results of the analysis prerequisite test including the normality test and the homogeneity test. Obtained data is normally distributed and data is not homogeneous distribution. Then proceed with the Mann-Whitney non-parametric test, the result is that a simple algebraic demonstration can construct students' ability to understand mathematical concepts in the experimental class and the control class.

From the results of the hypothesis testing data using the Mann-Whitney test, the result is a reject H_0, which means that algebraic learning aids can construct students' ability to understand mathematical concepts. From the Effect Size test, it was obtained 0.6227, so it can be concluded that the effect of making algebraic cookies to construct students' ability to understand concepts is low. Table 3 shows the average mathematics learning outcomes of students. It can be seen that the experimental class students are higher than the control class students.

Table 3. Recapitulation of Student Math Learning Instrument Test Results

\begin{tabular}{|c|c|c|c|c|}
\hline class & $\begin{array}{c}\text { Maximum } \\
\text { Score }\end{array}$ & $\begin{array}{c}\text { Average } \\
\text { Score }\end{array}$ & $\begin{array}{c}\text { Average } \\
\text { Value }\end{array}$ & Percentage \\
\hline Experiment & \multirow{2}{*}{60} & 43,6944 & 72,8241 & $73 \%$ \\
\cline { 1 - 3 } Control & & 35,1613 & 58,6022 & $59 \%$ \\
\hline
\end{tabular}

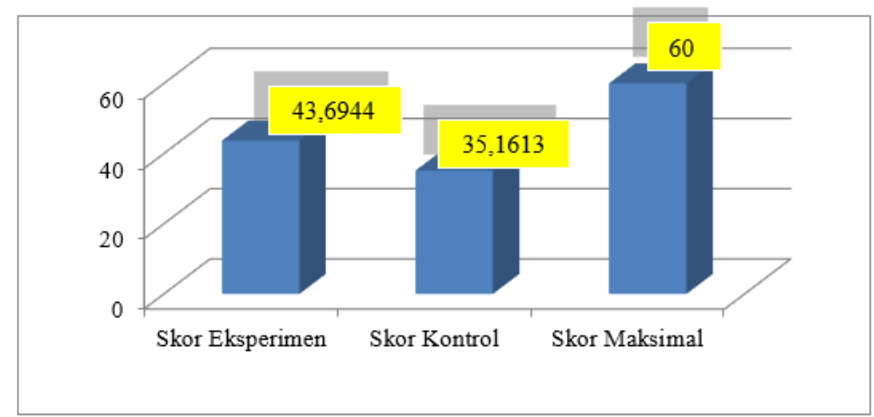

Fig 2. Average Math Learning Outcomes of Experimental and Control Class Students

Figure 2 shows that the average ability to understand mathematical concepts of students who use algebraic learning aids is higher than students who do not use algebraic teaching aids. From Figure 2, it can be seen that the maximum score is 60 with the experimental class achieving a score of 43.6944 or $73 \%$ of the maximum score, while the control class achieving a score of 35.1613 or $59 \%$ of the maximum score of 60 or $100 \%$. 


\section{Conclusion}

Based on the results of the study, the average score obtained by students who used algebraic Kenik was higher than students who did not use algebraic teaching aids. Thus, it can be concluded that the making of algebraic Kenik can construct the ability of grade VII students to understand mathematical concepts in the material of one-variable linear equations at SMP Negeri 13 Jakarta.

\section{References}

[1] Agustina, Lisna (2016). Upaya Meningkatkan Kemampuan Pemahaman Konsep dan Pemecahan Masalah Matematika Siswa SMP Negeri 4 Sipirok Kelas VII Melalui Pendekatan Matematika Realistik (PMR). Jurnal Eksakta, 1(1), 1

[2] Kemendikbud (2013). Model Pembelajaran Penemuan (Discovery Learning)

[3] Lestari, Karunia Eka, dkk. (2017). Penelitian Pendidikan Matematika. Bandung: PT Refika Aditama.

[4] Mz, Ah. Hermana (1984). Alat Peraga Dan Komunikasi Pendidikan. Bandung: Medal Agung.

[5] Nahdi, Dede Salim (2015). Meningkatkan Kemampuan Berpikir Kritis dan Penalaran Matematis Siswa Melalui Model Brain Based Learning. Jurnal Cakrawala Pendas, 1 (1), 14

[6] Rahma, A.A., dkk. (2018). Pengaruh Penggunaan Alat Peraga Batang Napier Terhadap Kemampuan Pemahaman Matematika Siswa Kelas VII SMP Negeri 4 Kuala. Jurnal Genta Mulia, 9 (1), 37

[7] UHAMKA. 2019. Pedoman Penulisan Karya Ilmiah Skripsi, Makalah dan Artikel. Jakarta: UHAMKA. 